DOI: https://doi.org/10.47405/mjssh.v6i2.664

\begin{tabular}{|c|c|}
\hline 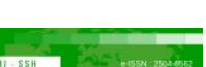 & Malaysian Journal of Social Sciences and Humanities (MJSSH) \\
\hline Malaysian Journal of & Volume 6, Issue 2, February 2021 \\
\hline (Mu-ssH) & e-ISSN : 2504-8562 \\
\hline & $\begin{array}{l}\text { Journal home page: } \\
\text { www.msocialsciences.com }\end{array}$ \\
\hline
\end{tabular}

\title{
A review on Innovation and its Strategic Importance to the Growth of Small and Medium Enterprises (SMEs)
}

\author{
Siti Noraisah binti Musneh'1,Sylvia@ NabilaAzwa Ambad ${ }^{1}$, Rosmimah Mohd Roslin² \\ 1University Teknologi MARA, Cawangan Sabah, Kampus Kota Kinabalu \\ ${ }^{2}$ Arshad Ayub Graduate Business School, Universiti Teknologi MARA \\ Correspondence: Siti Noraisah binti Musneh (aisyahsnmmf@gmail.com)
}

\begin{abstract}
This is a conceptual paper to review the innovation concept and determine the strategic importance of innovation towards the growth of Small and Medium-sized Enterprises (SMEs) globally. The study reviews the extant literature on the role of innovation in keeping SMEs competitive and sustainable in their business. This study's findings show the evidence from past literature on the importance of innovation to SMEs' growth, and its effect on SMEs if they failed to innovate. Another information that SMEs can gain when reading this paper is the definitions of innovation viewed from different perspectives and help SMEs get involved with relevant innovation activities.
\end{abstract}

Keywords: innovation, competitiveness, Small and Medium-sized Enterprises (SMEs)

\section{Introduction}

Business growth is a significant indicator of SME success, while the absence of growth will lead to SMEs likelihood failure or inability to survive. Firm survival and performance are usually related to the growth of the business. One strategy to ensure that business growth can be realised is expanding and improving its products through innovation (Golovko \& Valentini, 2010). SMEs are expected to assume a greater role, not only as an enabler but as a key driver of economic growth. SMEs' competitiveness is a critical area and should be a concern to achieve SME Corp's mission in promoting competitive, innovative, and resilient SMEs through effective coordination and business support provision. SMEs are key players in the economy and the wider eco-system of firms. Enabling them to adapt and thrive in a more open environment is essential for boosting economic growth and globalisation. Across countries and at all levels of development, SMEs have an important role in achieving the Sustainable Development Goals (SDGs) by promoting inclusive and sustainable economic growth, providing employment and decent work for all, promoting sustainable industrialisation and fostering innovation, and reducing income inequalities.

The changing in an organisation can be shaped by various current trends, including managerial innovation. Innovation has become a central issue for an organisation in an increasingly complex and challenging world, which will help the organisation reach a productive and efficient business. Innovation is one of the ingredients for a business to survive and grow and stay relevant. In the current scenario, to achieve long-term success, an organisation needs to support and enhance its employees' innovative potential rather than focusing only on research and development (R\&D) professionals, scientists, or specialists. Innovation is crucial for an organisation to survive and prosper in today's 
environment and is perceived to be one of the core competences of a successful firm (Chen et al., 2012). Embracing innovation will enable the organisation to stay relevant in the industry. In addition, to keep pace with rapid changes in the business environment and maintain a competitive edge, organisations need to innovate, not only by exploring new ideas but also to implement those ideas. Being innovative will make the organisation more responsive to external demands, more streamlined and agile, and more ecologically sustainable. Consequently, innovation has become a central issue for organisations in an increasingly complex and challenging world. In facing competitive challenges, organisations must improve their approaches to become more innovative and novel in delivering products and services. Innovation will help to increase business efficiency and productivity.

In Malaysia, 31\% of the GDP was contributed by SMEs, representing the largest percentage of total business establishment, which is $98.5 \%$ or 907,065 . The largest proportion is microenterprise $(76.5 \%)$, followed by the small enterprise (21.2\%), and only $2.3 \%$ is from the medium enterprise (Department of Statistik Malaysia, http://www.dosm.gov.my). Normah (2006) asserted that SMEs are notable players, especially to the country's economy and the firms' broader eco-system. The establishment of SMEs would facilitate Malaysia's business to become more competitive in today's global tough environment. Therefore, competitiveness among SMEs is a critical area that should be a concern. Regardless of SMEs' importance to the country's economy, SMEs' performance in Malaysia still has not achieved the target. The SME census 2011 in the SME Master plan for the year of 2012-2020 as cited by National SME Development Council (NSDC) (2014) reported that $42 \%$ of SME newcomers in the year 2000 were unable to sustain their business through 2005. Bernama (2017) quoted Ambank's Managing Director speech during the launching of Entrepreneurship Challenge event that within the first three (3) years of establishment as SMEs, almost $80 \%$ of them could not survive their business. Besides, the increasing instances of business failure among the SMEs became a recurrent issue concerning the critical problems affecting the survival of the SMEs (Sallem et al., 2017). The high rate of failure is one of the factors contributing to the low performance of SMEs. It was reported that almost 50\% of SMEs worldwide were unable to sustain their business with a significant failure within the first five (5) years of the establishment; while two-third failed within the first ten years of establishment (Small Business Administration (SBA), 2012; De Geest, et al., 2015). As reported by the latest statistics, the failure rate is consistent over the years (as of March 2016). SMEs in Malaysia share a similar situation with many of them failed within the first five years (Kee-Luen, Thiam-Yong, \& Seng-Fook, 2013; Bureau of labour Statistics, 2016), of which Chong (2012) and Ahmad and Seet (2009) noted some $60 \%$ failure rate. Despite the many programmes conducted to support and educate SMEs, not all SMEs experienced positive growth (Hove \& Tarisai, 2013).

As the resource of economic competitiveness, the SME sector and innovation have become a priority issue. Innovation is the result of employees' creativity, whereby all innovation begins with creative ideas. According to Li and Zheng (2014), to achieve and sustain a competitive advantage, and survive, SMEs must continuously innovate. It needed the organisation to think about different ways and strategies to be a sustainable and competitive organisation in the industry. Organisations that failed to innovate can be at risk and potentially diminish their ability to sustain or gain a competitive advantage. One way for the organisation to think creatively is by being innovative in all aspects of the business (Jafri, 2010). The CEO of SME Corp (2019) also mentioned that Innovation is a key for survival in any business, no matter its industry. Without innovations or new inventions, a business might not last long and tend to be displaced." Thus, this conceptual paper is developed to identify the importance of innovation on SMEs and the effect of being unable to innovate by analysing previous studies related to innovation and SMEs. Therefore, the paper generates the following questions:

i. What is innovation?

ii. What is the importance of innovation on Small and Medium Enterprises (SMEs)?

This conceptual paper is significant because it will provide extended knowledge of the importance of innovation to SMEs' business growth from past studies. 


\section{Literature Review}

This section explains about SMEs in Malaysia, in terms of categories and performance. Next, it raises the debate on the meaning of innovation, leading to difficulties in the definition process. This study then presents the definition of innovation from multiple disciplines to enhance the understanding of innovation and how to become innovative to answer the first research question: "what is innovation?'. This study explores the extant literature on the importance of innovation to SMEs growth, which answers the second research question on the importance of innovation towards SMEs' growth.

\section{SMEs in Malaysia}

There are various definitions of SMEs. The World Bank (1984), the UN Industrial Development Organization (1985) and the Asian Development Bank (1990) segregated SMEs into three categories, as mentioned by Anggadwita and Mustfid (2013). The categorise is based on the quantity of labour: 1) small-sized firms employing less than 50 workers; 2) medium-sized employing between 50 and 199 workers. Based on the SME Annual Report 2017/18, the definition of SME remained with the existing qualifying criteria, such as sales turnover and employment. However, under the new definition of SMEs, the threshold has been increased.

Table 1: New definition of SME by Size of Operation

\begin{tabular}{|c|c|c|c|}
\hline Category & Micro & Small & Medium \\
\hline Manufacturing & $\begin{array}{l}\text { Sales turnover less than } \\
\text { RM300,00 Employees } \\
\text { less than } 5\end{array}$ & $\begin{array}{l}\text { Sales turnover from } \\
\text { RM300,00 to less than } \\
\text { RM15 million } \\
\text { Full-time employees from } \\
5 \text { to less than } 75\end{array}$ & $\begin{array}{l}\text { Sales turn over from } \\
\text { RM15million to not exceeding } \\
\text { RM50million } \\
\text { Full-time employees from } 75 \\
\text { to not exceeding } 200\end{array}$ \\
\hline $\begin{array}{l}\text { Services and } \\
\text { other sectors }\end{array}$ & $\begin{array}{l}\text { Sales turnover less than } \\
\text { RM300,00 } \\
\text { Employees less than } 5\end{array}$ & $\begin{array}{l}\text { Sales turnover from } \\
\text { RM300,000 to less than } \\
\text { RM3 million } \\
\text { Full-time employees from } \\
5 \text { to less than } 30\end{array}$ & $\begin{array}{l}\text { Sales turnover from } \\
\text { RM3million to not exceeding } \\
\text { RM20million } \\
\text { Full time employees from } 30 \\
\text { to not exceeding } 75\end{array}$ \\
\hline
\end{tabular}

Source: Department of Statistic Malaysia

In Malaysia, SMEs represent the largest percentage of total businesses establishment, which is 907,065 or $98.5 \%$. The largest proportion is microenterprise $(76.5 \%)$ followed by the small enterprise $(21.2 \%)$ and medium enterprise (2.3\%). SMEs contribute to the nation's economic development and strengthen the Malaysian businesses' resilience in facing competitive and global environments (Normah, 2006). In 2017, SMEs contributed 37.1\% to the overall GDP. SME sector includes various fields, such as the service sector, manufacturing, agriculture, trade, mining, and others. SMEs economic activities are largely contributed by the service sector at $89.2 \%$, followed by manufacturing (5.3\%), construction (4.3\%), agriculture (1.1\%) and mining and quarrying with only $0.1 \%$ (Department of Statistics Malaysia Official Portal, 2019).

\section{Definition of Innovation}

Innovation has been a topic of interest for many researchers in various fields; not only to strategic management researchers but also in human resource management, operations management, entrepreneurship, research and development, information technology, engineering and product design, and marketing and strategy. The various fields involved in innovation research have led to numerous definitions of innovation according to the different perspectives. The Oslo Manual's extensive work gives the basic lesson that it is difficult to define innovation.

Nevertheless, it is important to understand the definition of innovation to avoid negative consequences, especially to a business or an organisation. Without a comprehensive understanding of innovation, one might suggest an organisation should be involved with all forms of innovation 
(Cooper, 1998). Therefore, to ensure that a business entity incorporates or implements the right kind of innovation, it is crucial to understand the meaning of innovation. According to a study by Baregheh, Rowley, and Sambrook (2009), there are six (6) attributes that formed the basis of innovation concept: the nature of innovation, types of innovation, stages of innovation, social contexts, means of innovation, and aim of innovation. Meanwhile, Cooper (1998) suggested that innovation is a process or a discrete event. Cooper (1998) also proposed the scope of behaviour that constitute an innovation. Consequently, several definitions of innovation have been developed according to various attributes, such as the six attributes mentioned by Baregheh et al. (2009).

A precise definition of innovation is vital for an organisation to determine whether its business activities are to be performed in-house or outsourced. Innovation is typically related to novelty. According to Damanpour and Evan (1984), innovation is a widely used concept, and the term can be defined differently to explain the particular requirement and the nature of a specific study. Baregheh et al. (2009) mentioned that organisational innovation could be related to products, services, operations, processes, and people. The most common and basic definition of innovation was given by Thompson (1965); innovation is the generation, acceptance, and implementation of any new ideas, processes, products, or even services. Wong (2008) quoted West and Anderson (1996), giving a rather similar definition to Thompson, whereby innovation is considered an effective application of new processes or product to the organisation, which is expected to benefit the entire organisation, including stakeholders.

Meanwhile, according to Kimberly (1981), innovation is defined based on three (3) stages. The first stages view innovation as a process, then as distinct elements, such as products, programmes, or services, and the last stage is innovation as an attribute of the organisation. Innovation from the standpoint of knowledge management also holds a different perspective. Plesis (2007) stated that innovation in knowledge management forms new knowledge and ideas to help the business achieve its outcomes, aiming to improve the internal business and processes and structures and design marketdriven products and services. Based on these viewpoints, innovation includes both radical and incremental innovations.

Innovation is also defined differently in the manufacturing sector. Bessant and Tidd (2007) quoted Freeman (1982), suggested that innovation in the manufacturing sector is "the technical, design, manufacturing, management, and commercial activities involved in the marketing of a new or improved product or the first commercial use of new or improved processes or equipment". Another definition by Bessant et al. (2005) took Schumpeter's suggestion that considers the renewal process in an organisation as innovation. Despite all the definitions from different perspectives, innovation can appear in all sectors of economic activities in terms of products, processes and services spanning from traditional to high-tech companies, public to market, industrial, agricultural or tertiary.

\section{Importance of innovation to SMEs growth}

As one of the main sources of business growth, the role of innovation has been receiving more attention from researchers doing empirical studies and theoretical works. Joseph Schumpeter is the first economist who focuses on the importance of innovation as a source for business growth. Thus, innovation is performed to renew asset endowment. Numerous studies have empirically shown the positive impact of innovation on SMEs' growth. Other researchers found that innovation can be considered the main ingredient of a business or corporate survival and growth (Zahra \& Covin, 1994). Accordingly, many researchers agreed that to be able to sustain in a competitive business world, organisations need to innovate continuously and promote innovatively.

Innovation is a key engine of SMEs sustainability that could positively impact their growth in several ways. According to Cho and Puchik (2005) and Cohen and Klepper (1996), improving the product features through innovation will help the firm create new and uncontested product market and increase consumers' willingness to pay. At present, to be competitive in business, innovation is a crucial aspect of concerned. An organisation that embraced innovativeness will produce a new or improve the present products before their competitors, which boost the organisation's market share. 
Competitiveness among businesses, either in the inter- or intra-industry, has become more intense in today's business environment with innovation. Nowadays, companies that were previously in the energy industry have become part of the Telco industry. The Star Online reported that Tenaga Nasional Berhad (TNB), a company in the energy industry, will enter the telecommunication sector by penetrating the broadband market. In this scenario, innovation is called a game changer when a firm wins the competition in business perspective by being better than their competitors and being dynamic and agile following the current environment or when necessary (Lafley \& Charen, 2010).

In addition, innovation is also deemed an organisational strategy for business growth. Distanont and Khongmalai (2018) asserted that this strategy allows organisations create a long-term competition by gaining knowledge, technological skills, and experience creativity and developing and introducing innovative ideas in terms of products, process, or business model. Previously, businesses view innovation as part of the Research and Development $(R \& D)$ aspect. However, nowadays, innovation is no longer part of the R\&D department, but become the core foundation of how a business operates. Innovation is the key to decision-making and helps set and choose the organisation's objectives and goals (Lafley \& Charen, 2010). This is supported by OECD (1981: 15-16), which noted that innovation consists of all the scientific, commercial and financial steps necessary for the successful development and marketing of new or improved manufactures' products, the commercial use of new or improved processes or equipment or the introduction of a new approach to social service. $\mathrm{R} \& \mathrm{D}$ is only one of these steps.

\section{Methodology}

This conceptual paper is based solely on reviewing and analysing research and data from the related literature. This research was conducted using the Google search engine. References are based on online databases only, such as Scopus, Science Direct, and Google Scholar. The advance search is limited to terms, such as "firms' innovation", "SMEs growth" as well as "importance of innovation" from the year 2015 to 2020. For Science Direct, the subject area was limited to Business, Management, and Accounting; whereas, for Scopus, the search is limited to areas in Social Science and Business, Management and Accounting that used the English language only. The References are taken strictly from articles, journals and book chapters. The most helpful past literature was a multidisciplinary definition of innovation and SME innovation, exporting and growth: A review of existing evidence.

Table 2: Summary of searching via online database

\begin{tabular}{lccc}
\hline \multirow{2}{*}{\multicolumn{1}{c}{ Keywords }} & \multicolumn{3}{c}{ No. of articles/journal/book chapter } \\
\cline { 2 - 4 } & ScienceDirect & Scopus & Google Scholar \\
\hline Firms innovation & 218 & 29,180 & 220,000 \\
SMEs Growth & 28 & 21,441 & 44,800 \\
Importance of innovation & 322 & 59,828 & 842,000 \\
\hline
\end{tabular}

\section{Conclusion}

SMEs play a major role in economic growth as most of these establishments are the sources for job opportunities, which help reduce the unemployment rate and generate income and export revenues of the country. Despite the importance of innovation to SMEs' growth, understanding the meaning of innovation is crucial. A good innovation strategy needs to be applied for a business that believes innovation is one of the keys to their business's survival and growth. As innovation can be implemented through numerous ways, such as process, product, market, and operational definition, the respective SMEs need to define the type of innovation suitable to their nature of business based on the output they expected from innovation activities. Thus, this paper is expected to help SMEs better 
understand the definition of innovation and give an insight into the importance of innovations towards SMEs' growth.

\section{Limitation}

In general, every business entity understood the need to utilise resources properly to achieve its business objective and attain superior performance. Nevertheless, not many businesses succeed in attaining superior performance, and not much is known about drivers of innovation or how innovativeness influences performance (Hult, Hurley, \& Knight, 2004). As this paper is only a conceptual paper, data were not collected to enable generalisation to other countries. Moreover, this paper only focused on the importance of innovation to SMEs and did not cover factors hindering innovation adoption among SMEs. Thus, this study calls for future researchers to conduct empirical studies on factors deterring innovation adoption among SMEs. Similar studies are encouraged to be conducted in other countries.

\section{References}

Ahmad, N. H., \& Seet, P.-S. (2009). Dissecting Behaviours Associated with Business Failure: A Qualitative Study of SME Owners in Malaysia and Australia. Asian Social Science, 5(9). doi: 10.5539/ass.v5n9p98

Anggadwita, G. \& Mustafid, Q.Y. (2013). The $5^{\text {th }}$ Indonesia International Conference on Innovation, Entreprenuership, and Small Business (IICIES 2013).

Baregheh, A., Rowley, J., \& Sambrook, S. (2009). Towards a multidisciplinary definition of innovation. Management Decision, 47(8), 1323-1339. doi: 10.1108/00251740910984578

Bernama. (2017, September 8). Press release: Ambank launches entrepreneurship challenge 'AMBANK BIZRACE'. Bernama MREM. Retrieved from http://mrem.bernama.com/ viewsm.php?idm $=29994$

Bessant, J. \& Tidd, J. (2007). Innovation and Entrepreneurship. Innovation and Entrepreneurship.

Bureau of Labor Statistics. (November 2017). Survival rates of establishments, by year started and number ofyears since starting, 1994-2015. Retrieved from https://data.bls.gov/cgibin/print.pl/bdm/entrepreneurship/bdm_chart3.htm

Chen, S. (2017). The relationship between innovation and firm performance: A literature review.

Chen, Y. C., Lee, C. S., Tsui, P. L., \& Yu, T. H. (2012). Investigating organizational open innovation climate and relationships. Australian Journal of Business and Management Research, 2(5), 6975

Cho, H., Pucik, V. 2005. Relationship between innovativeness, quality growth, profitability, and market value. Journal of Strategy Management, 24(26), 525.

Chong, W. Y. (2012). Critical success factors for small and medium enterprises: Perceptions of entrepreneurs in urban Malaysia. Journal of Business and Policy Research, 7(4), 204-215. Retrieved from http://wbiaus.org/14.\%20Wei.pdf

Cohen, W. M., \& Klepper, S. (1996). Firm Size and the Nature of Innovation within Industries: The Case of Process and Product R\&D. The Review of Economics and Statistics, 78(2), 232. doi: $10.2307 / 2109925$

Damanpour, F., \& Evan, W. M. (1984). Organizational Innovation and Performance: The Problem of "Organizational Lag". Administrative Science Quarterly, 29(3), 392. doi: 10.2307/2393031

De Geest, D. S., Follmer, E. H., Walter, S. L., \& O’Boyle, E. H. (2015). The Benefits of Benefits: A Dynamic, Approach to Motivation-Enhancing Human Resource Practices and Entrepreneurial Survival. Journal of Management.1-30.

Distanont, A., \& Khongmalai, O. (2018). The role of innovation in creating a competitive advantage. Kasetsart Journal of Social Sciences. doi: 10.1016/j.kjss.2018.07.009

Golovko, E., \& Valentini, G. (2010). Exploring the Complementarity between Innovation and Export for SMEs Growth. SSRN Electronic Journal. doi: 10.2139/ssrn.1091130

Hove, P., \& Tarisai, C. (2013). Internal factors affecting the successful growth and survival of small and micro agri-business firms in Alice communal area. Journal of Economics, 4(1), 57-67. 
Hult, G. M., Hurley, R. F., \& Knight, G. A. (2004). Innovativeness: Its antecedents and impact on business performance. Industrial Marketing Management, 33(5), 429-438. doi: 10.1016/j.indmarman.2003.08.015

Jafri, M. H. (2010). Organizational Commitment and Employee's Innovative Behaviour. Journal of Management Research, 10(1), 62-68.

John Wiley, 462 pp., ISBN: 978-0-470-03269-5. pbk. International Journal of Entrepreneurial Behavior \& Research, 14(2), 121-124. doi: 10.1108/13552550810863107

Li, X., \& Zheng, Y. (2014). The Influential Factors of Employees' Innovative Behavior and the Management Advices. Journal of Service Science and Management, 07(06), 446-450. doi: $10.4236 / j s s m .2014 .760$

Mohd Sallem, N. R., Mohd Nasir, N. E., Mohd Nori, W. M. N., \& Che Ku Kassim, C. K. H. (2017). Small and Medium Enterprises: Critical Problems and Possible Solutions. International Business Management, 11, 47-52.

Normah (2006) Normah, M. A. (2006). SMEs: Building block of economic growth. Paper presented at the National Statistical Conference, Malaysia. 4 - 5 September.

NSDC. (2014). SME Annual Report 2013/2014. September 2014. Retrieved from:http://www.smecorp.gov.my/vn2/node/1475

Oslo Manual: READ online. (n.d.). Retrieved from https://read.oecd-ilibrary.org/science-andtechnology/oslo-manual_9789264013100-en. Hult, Hurley, \& Knight, 2004

SBA. (2017). Small Business Administration U.S. Small Business Administration, Office of Advocacy. August 2017. Retrieved from https://www.sba.gov/sites/default/files/advocacy

Zahra, S. A., \& Covin, J. G. (1994). The financial implications of fit between competitive strategy and innovation types and sources. The Journal of High Technology Management Research, 5(2), 183-211. doi: 10.1016/1047-8310(94)90002- 